\title{
FACING DIVERSITY OR LONGING FOR HOMOGENEITY? DISCUSSION WITHIN THE DRC ON RELIGIOUS EDUCATION
}

\author{
Wolfram Weisse \\ University of Hamburg \\ Germany
}

\begin{abstract}
The Dutch Reformed Church (DRC) in South Africa can be regarded as one of the important pressure groups for religious education (RE) in schools. Based on a case study this contribution focuses on the following question: Does the DRC opt for a traditional, Christian National approach of RE in public schools or does it open up to new forms of RE, reflecting the religious and cultural diversity in the country? The contribution investigates this question from three perspectives: The development of ideas on the official level of synodical statements, the semi-official level of reports in the church's newspaper Die Kerkbode, and the opinions of students at grassroots level. We find both an increasing willingness to open up to diversity and a line of thought that leans toward isolation and disrespect of other religions. The question of accepting diversity in the field of religion is crucial for the broader field of diversity in the country.
\end{abstract}

Key Concepts: Dutch Reformed Church, traditional RE, semi-official reports, diversity

\section{Introduction}

Generally speaking there seems to be a positive attitude towards diversity in South Africa. The symbol of the rainbow-nation gives evidence of a general feeling that different identities?, traditions, languages etc. may form a magnificent and colourful unified whole. But what happens if concrete problems must be solved and critical questions arise? Is there a strong will to establish structures in education and society in order to support or even actively promote a multilingual attitude in the public sphere? And what about peoples' decisions to do both: To speak out in general terms for a multilingual society and to send their own children to a school with English as the language of learning, even if the family's background is not an English one? (A question here is whether choosing an English school for non-English children really cultivates a "multilingual attitude" ...CA).

There is often a tension between general statements and concrete behaviour and decisions. It is not easy to comment on the question, why this is the case and how to value it. Maybe this tension is a sign of a society undergoing a transformation and maybe these contradictions are even necessary - at least for a while - because for both positions there are good justifications: The general option is a decision for diversity, but there are also concrete decisions towards strengthening the own culture, tradition and language. The first could be a long-term desire, the second a short-term necessity. Or: The first could be the adaptation to a dominant public discourse and the second an expression of personal feelings. 
In the following I would like to enter a field, where the term diversity has played a major role over at least the last 50 years. Members of the DRC fostered the idea of a specific form of diversity, namely that different nations and language groups/ethnic groups have their own rights to exist independently and this should be supported by adequate political structures. This was the basis of the Apartheid-programme and this idea eventually became an ideology that manifested in the suppressive dominance of one population group over the rest of South Africa's inhabitants. Under these circumstances diversity was shaped by power and used exclusively in such terms. The pre-1994 language policy that promoted Afrikaans (with support for English but not for indigenous African languages) was a sign of such a form of politics. Another sign was a school system based on the idea of Christian National Education that went beyond simple Christian dominance in RE (Coertzen, 2002; Swart, 2002). After the end of Apartheid it was more than evident, that this form of diversity could not be sustained any more (Roux, 2000; Chidester, 2003). Diversity needed to be linked to equal rights in school and society (Mitchell, 2002; Jackson, 2003). The implications of such a task go far beyond the focus of my paper that will focus on the question of how diversity has been discussed within the DRC with regard to RE. Here I shall address the following questions:

- Has RE been a field of importance reflected in official and semi-official statements of the DRC within the last decade?

- What do official and semi-official statements show: A tendency to opt for diversity (and in which way) or to defend old positions?

- How do students in Stellenbosch and Pretoria see the importance and the priorities of RE today?

Gordon Mitchell has identified RE as a testing-ground for multicultural education (Mitchell, 1993). So I will try to test, even if only limitedly, how RE is seen by the DRC on different levels, mainly with regard to notions of diversity.

\section{Discussions within the DRC on RE}

Decisions of the General Synods

Within a time span of about ten years the outlook on RE has changed completely. From the time after World War II till the end of the 1980s the entire school system in South Africa was called Christian National - and the word Christian could be read as reformed if one considers how white DRC-theologians understood it. The DRC was in a position of power both in cooperating with state authorities in defining the terms and the reality of the educational system in South Africa. By the end of the 1990s the DRC evidently had lost such power: In view of education it became not much more than a pressure group trying to influence the government's policy on RE. Let me explain this development from the middle of the 1980s till the present on the basis of official statements of the DRC, expressed through their General Synods which take place every four years:

1986: The perspective of uncontested power in a context of Christian National Education with the government as naturalally

In the minutes of the 1986 General Synod of the DRC an uncontested self-understanding is evident. Here the principle of Christian National Education is called an unwavering 
principle of the DRC. ${ }^{1} 1986$ still marked a time when the leaders of Church and government met regularly, and the outcome of such meetings could result in statements like those printed in the minutes, that education should continue to have a Christian basis. ${ }^{2}$ According to the principles of Apartheid it was emphasised that each major population group should have its own system of education. ${ }^{3}$ The situation still seemed to be as good as ever. This self-understanding is reflected in a resolution of the 1986 Synod that reads: The Synod expresses its gratitude and appreciation towards the government (owerheid) for the maintenance of Christian National Education as laid down in article 39 of 1967.

In 1986 the political system of Apartheid still held sway, although resistance was growing and the government's declaration of a state of emergency showed that times for both the black population and the rulers of the country were getting harder. The synod in 1986 had other more pressing issues than RE on its agenda, namely the question of whether Apartheid still could be justified on biblical grounds. With regard to education there was no new or special effort. The clear tendency was just to continue as before and to acknowledge the government for guaranteeing a proper framework.

\section{0: The perspective of a slight irritation - the statement of principles for (Protestant)} Christian education in a separated society

In an application to the General Synod in 1990 we find a description of the role-players in education: Church, state and parents. The state is considered to be responsible to grant every child the possibility to prepare for life $^{5}$ according to his/her abilities, interests, religion and world-view. Still in full accordance with the politics of separation it is emphasised that the Church expects a Protestant-Christian character in an education system, differentiated along the lines of culture. ${ }^{6}$ As definition of what Christian education could be we find the following definition in the minutes of the Synod: Christian education means that general school education should always take the Bible and Christian principles into account, that Bible lessons should always be given the necessary attention and that the faith of children with a Christian background will be built up and strengthened instead of being undermined and contradicted. ${ }^{7}$ Here we notice both traditional demands and new fears.

In 1990 the open transition-phase in South Africa had just started. Nelson Mandela had been released from prison in the beginning of the year and the Synod that took place in October, was occupied with reflecting in general about what this could mean for the church. Willie Jonker, theologian from Stellenbosch, caused a massive reaction within the DRC saying publicly that the church had failed in the years of Apartheid. He did not relate this

Agenda Alg. Sinode 1986, p. 8: Die beginsel van Christelik-nasionale onderwys was tot hiertoe nog altyd die beginsel waarop die Kerk gestaan het. Translation of this and the following quotations into English by the author.

2 Op.Cit., p. 190: Die behoud van die Christelike grondslag van die onderwys.

3 Op.Cit., p. 190: Onderwys as eie saak vir elke hoofbevolkingsgroep.

$4 \quad$ Op.Cit., p. 188: Die Sinode betuig sy dank en waardering teenoor die owerheid vir die behoud van Christelik Nasionale Onderwys soos vervat in Wet 39 van 1967.

$5 \quad$ Agenda Algemene Sinode 1990, p. 184: Vir sy lewenstaak voor te berei.

6 Op.Cit., p. 184: Die Kerk beywer hom vir die Protestants-Christelike karakter van kultuur-gedifferensieerde onderwys.

7 Op.Cit., p. 602: Met "Christelike onderwys" word bedoel dat die onderrig in skole steeds rekening moet hou met die Bybel en die Christelike beginsels, dat Bybelonderrig steeds die nodige aandag ontvang en dat die geloof van kinders uit Christelike huise opgebou en gesteun moet word in plaas van om afgebreek en weerspreek te word. 
directly to the question of education. Here attention was directed to how deeply rooted and widely established the ideas of separate development were.

1994: The perspective of defence - the struggle for Christian schools and the beginning of alliances with other Christian churches formulating priorities to teach religion

In a time when the continued existence of private confessional schools had become endangered, the Synod of 1994 expressed its concern in the following way: The church ... will have to fight with all means and continuously negotiate for the right of parents to send their children to schools with a Christian and culturally focussed foundation. ${ }^{8}$ Congregations were encouraged by the Synod to support this aim. The minister of education was to be contacted and provisions were to be made for ensuring an academic and school related subject, namely biblical studies (p. 359). Whereas in former times the DRC felt confident that it could fight for its own interests, it now looked for allies. In a resolution on Teaching of Religion - drafted by representatives of at least 80 Christian denominations and published in the minutes of the Synod - one can recognise the dichotomy of a formal opening up to others while maintaining the defence of a Christian based religious education. This is illustrated in the following passage from that resolution: We, as Christians, support the principle of religious freedom but not religious equality. As Christians we acknowledge that the diversity of religions, and their numbers in South Africa, should be considered in planning an education policy. The fact that Christians are vastly in the majority should also be taken into account. ... As Christians, we reject the idea of a compulsory, neutral, multi-faith religious education for our children. ${ }^{9}$ This argumentation contains an interesting mixture of defending the status quo and progressing towards recognition of other faith communities. The concrete aim of the resolution was the call for two subjects at school: Religious education according to the ethos of the school on the one hand and the formerly established subject biblical studies as an optional examination subject on the other hand.

1994 was the year of the election that brought Nelson Mandela and the ANC to power with F.W. de Klerk and the National Party as partners in the government of national unity. In the phase from 1990 to 1994 new concepts of state and society were discussed in political circles and in the public sphere. In the realm of education a huge renewal process was being organised, called NEPI: The New Education Policy Initiative. In this frame concepts and pilot projects for an interreligious Religion Education were developed (Chidester, Mitchell, Omar and Phiri, 1994). The DRC did not support this approach. To the contrary, it tried to find allies that would fight for a Religious Education approach based on the influence of the churches and structured by separation along the lines of different religions. In a time of general change and opening-up of the education system, the DRC chose to concentrate on the defence of their own interests.

1998: The perspective of looking for spaces to ensure a Christian education - demands towards the government, old interests of Christian education in new forms

Article 15 of the South African Constitution (Law 108) of 1996 guarantees freedom of conscience and religion and provides the possibility of religious services in schools along certain lines. The Synod which took place in 1998 referred to this article of the

$8 \quad$ Minutes of the 1994 Synod, p. 148: Die kerk sal ... alles in die stryd moet werp en voortdurend beding om te verseker dat ouers die reg sal hê om hulle kinders in skole met 'n Christelike en kultuurgerigte grondslag te laat opvoed.

9 Op. cit. 361. 
constitution, ${ }^{10}$ in order to plead for the possibility that churches be allowed to participate in holding services and in offering religious education as a subject in schools. Religious education should - as the Synod stated - have a properly suited place in the new education policy, the Curriculum 2005. ${ }^{11}$ In a resolution the government is called on to ensure religious education according to the abilities of the child and in line with general religious convictions and world views. ${ }^{12}$ In order to strengthen a Christian religious education the resolution underlines the necessity of cooperation between churches and non-church institutions. ${ }^{13}$ It pleads for old interests within a new frame and with a changed terminology. A new idea introduced here is that of ecumenical cooperation with other churches: Formerly the World Council of Churches was referred to as an international ally of the communists, and thus, until 1990 ecumenical was regarded to be an abusive word in the DRC.

In the period of the late 1990s the DRC changed its approach and tried to adapt to the new situation by using possibilities within the changing political and legal context. The long-term programme in the field of education - Curriculum 2005 - made provision for a new learning area called life orientation. Within the frame of life orientation religious questions could be dealt with - but it was not clear, in which way and with which concepts religious education would be provided for in Curriculum 2005. In response the DRC called on the government to ensure the continuation of Christian religious education in schools. The DRC started to become a pressure-group striving for its own interests. Allies were drafted from a range of different Christian denominations. This constitutes an opening up to others compared to the NGK's former practices; however, there hasn't been sensitivity to take it further, e.g. by entering into discussions with representatives of other religions in order to find common ground or to strive for an implementation of RE that takes into account the diversity of religions in South Africa.

\section{2: The perspective of a pressure group with the aim to secure a minimum of interests in the field of $R E$}

After the General Synod of 2002 there was a single focus with regard to RE, namely critical reactions towards proposals of the Minister of Education, Kader Asmal. In a common statement with leaders of other Christian Churches, which is included in the minutes of the Synod, ${ }^{14}$ the minister is sharply criticised for his proposal, to make schools available for religious observance as long as it is outside of school hours. ${ }^{15}$ Also criticised is the comment Kader Asmal made in the Manifesto on Values, Education, and Democracy - in August 2001 - that Religious education should be taught by trained professional educators who are motivated by educational outcomes, rather than by professional clergy. ${ }^{16}$ The resolution considered this implication that clergy are not motivated by educational outcomes to be unreasonable. Referring to the constitution, the resolution argues for religious observances in school hours. ${ }^{17}$ Curriculum 2005 is criticised because it can

10 The minutes also refer to School Law No 84 of 1996 and comments from the side of the department of education.

1 Minutes of the General Synod 1998, p. 110.

Op. Cit. 122.

Op.Cit., p. 123: met nie-kerklike instansies saam te werk...

Minutes of the General Synod 2002, p. 170-172.

Op.Cit., p. 171.

Op.Cit., p. 171.

Op.Cit., p. 172. 
potentially support state-controlled thinking. If the Curriculum is formulated and evaluated exclusively by the state the paradigm will be the same as in the case of Christelike Nasionale Opvoeding; only the content will be changed. ${ }^{18}$ What a shift in argumentation: As if it hadn't been the DRC itself who backed Christian National Education for decades! At the end of the resolution the government is called on to delay the implementation of the curriculum and to consult with the religious communities first.

I will summarise in two sentences. First: The DRC has developed very quickly from a power-player to a pressure group in society that still knows how to exert its influence in the public sphere. Second: The former role as strongest supporter and beneficiary of a monolithic Christian National Education seems to be forgotten; now a critical position towards the government dominates. As a new development the importance of directing churches' resources into the public school system, is recognised. This is aimed at finding a compromise between church and government, in order to secure the church's interests and to prevent the government from gaining a dominant position with regard to the instilling of values and religion. The next chapter shows that the DRC really opened up to new possibilities.

\section{Contributions and Discussions in Die Kerkbode}

Generally speaking Die Kerkbode, the journal owned by the DRC, showed medium-level interest in view of religious education, with a clear rising tendency in the year 2003. While during the 1990s not even half a dozen articles had been published on RE per year, the number of articles on this topic increased to 14 contributions in 2003. RE became front page news or was commented upon in editorials mostly when a change in public policy was at stake. In the first half of the 1990s we find critical reactions to suggested changes published in Die Kerkbode. This can be understood as reaction to the grassroots discussion and the public debate on education with regard to the NEPI-reports. From the middle of the 1990s to about 2000 Die Kerkbode reacted to Curriculum 2005 and its implications for RE. From 2001 onwards the interest rose in line with concrete announcements, drafts and finally the policy-report of the Minister of Education in September 2003 on Religion and Education. To sum up: The more precisely the ministry of education spelled out its policy, the more Die Kerkbode took an explicit interest in the theme of RE.

In the reports and comments of Die Kerkbode during the past 12 years we find two parallel trends: 1) a mirroring of the general development of thought on RE as expressed in the DRC's synods, characterised above, and 2) attention to a far greater variety of aspects and controversial points of view than in the synodical statements.

Where the general trend of articles in the first half of the 1990s is marked by headlines like Christian education hit in the heart or Christian education: DRC must persist ${ }^{19}$ we also find an article where quite different and self-critical questions are put forward. Under the headline Religion in school: Not a simple matter ${ }^{20}$ a front page article was published in Die Kerkbode in September 1994. It stated mainly that consideration must be given to the fact that more children from different cultural and religious backgrounds nowadays go to the same school. ${ }^{21}$ In view of the explicitly expressed uncertainty about the future of RE

18 Op.Cit., p. 171.

19 "Christelike onderwys só in hart getref" (Die Kerkbode 30.9. 1994) or "Christelike onderwys: NGK moet volhard" (Die Kerkbode 22.9.1995).

20 "Godsdiens op skool: dit lol" (Die Kerkbode 2.9.1994).

21 Op. Cit.: "Dit is veral die geval omdat al hoe meer kinders uit verskillende kultuur- en geloofsgroepe deesdae saam skoolgaan". 
three different opinions are given space: That of Dr Eduan Hay, who held the office of education for the General Synod of the DRC, that of Nico Koopman from the Uniting Reformed Church and finally that of Clem Marais from Namibia. The first underlines the necessity of a homogeneous RE at least in the first years of schooling: At a later stage children can also learn about other religions, but we have to watch out that younger children are not confronted with and confused by different religious orientations. ${ }^{22}$ This argument appears regularly in reports and comments of Die Kerkbode. It stands for an attitude, shaped by a position that prefers as little change as possible. This is not the case with the second opinion referred to in this article: Nico Koopman, student-pastor in the Uniting DRC, characterises the question of RE as a controversial and important one; he refers to the new possibilities in the constitution, but underlines: We have to be careful about a new form of Christian imperialism and should not use our numerical advantage to disadvantage and to suppress other religions. ${ }^{23}$ This is one of the very few voices in Die Kerkbode, where the question of power is raised, and where a self-critical point of view is expressed. The third opinion referred to in this article demonstrates new developments in $\mathrm{RE}$ in Namibia and shows that other constructions of RE in schools could be taken into consideration, e.g. the possibility of parallel classes of RE for different faith-groups. So this article highlighted different approaches to the theme of RE and could contribute to widen the horizon of the readers of that magazine.

In the second half of the 1990s reports and comments concentrated on Curriculum 2005. The general line was to dramatise the threats towards a Christian $\mathrm{RE}^{24}$ and to criticise the government, sometimes quite rudely. In an editorial of September 1998 we find a conclusion directed at the then Minister of Education, Dr. Sibusiso Bengu: The minister's words are disorganised. ${ }^{25}$ What a profound change in the manner of addressing members of the government within only a decade!

Die Kerkbode also gave space to controversies. One debate took place between the ultra-conservative Joey van Niekerk and the more progressive Dr Okkie Raubenheimer. Van Niekerk, former lecturer in education at the University of Pretoria, warned of the dramatic implication for RE within Curriculum 2005 and called on the readers to write letters of protest to the Minister of Education - and as a help to readers the address of the minister was added at the end of the article. ${ }^{26}$ In his response Okkie Raubenheimer, responsible for the education-section of the General Synod, tried to explain the framework of Curriculum 2005. He hinted at spaces open to interpretation and drew attention to the fact that in the first place the task of religious education is a responsibility of the parents. ${ }^{27}$ It is interesting to note that the official DRC delegate offered a more liberal outlook than a church member.

The debate was continued some years later. The same Joey van Niekerk published a long article in October 2001 with the headline: The problem with multi-religious edu-

22 Op. Cit.: "Kinders kan mettertyd op skool ook van ander godsdienste leer, maar ons moet daarteen waak om nie die kleiner kind met verskillende godsdiensoortuigings te konfronteer en te verwar nie."

23 Op. Cit.: "Ons moet versigtig wees vir 'n nuwe vorm van Christelike imperialisme en nie ons getallevoordeel gebruik om ander godsdienste te benadeel of te onderdruk nie."

24 See the headline on the front-page: "Christelike skole se voortbestaan bedreig", in Die Kerkbode, 20.9.1996.

25 The headline was: "Dit rym nie and the last sentence reads: Die minister praat deurmekaar", Die Kerkbode 9.9.1998.

26 See: Die Kerkbode 2.5.1997, J. van Niekerk: "Godsdiensonderrig: gevaarligte flikker met 'Curriculum $2005^{\prime \prime}$.

27 See the article in Die Kerkbode, 2.5.1997, "Christelike enderwys kán nog!" 
cation. ${ }^{28}$ This article would lend itself ideally for an analysis of every possible prejudice against a multi-religious RE. I quote only one passage that reads: How do young children learn to believe in their own God and to know Him better, to love Him and to serve Him, if they don't receive a thorough and pure education in their own faith during the years in which they are formed? Syncretism may perhaps be the dream and the final goal of New Agers and of Asmals and religion scientists of this world, but this surely is not what dedicated and faithful parents of the three monotheist religions would like for their children. ${ }^{29}$

$\mathrm{J}$ van Niekerk is so clear in her concept of what RE should be and in her judgements on a multi-faith RE that it needs no comment. She only made one mistake, and that is to incorporate findings of Cornelia Roux in her argumentation. Cornelia Roux is quoted in the following way: Her empirical studies showed [...] pupils were often unable to reproduce knowledge about their own religion in the classroom [...] It appears that Christian children in particular lack religious experiences. ${ }^{30}$ This caused Cornelia Roux to respond in the next edition of Die Kerkbode $e^{31}$ - and she did it in a profound way. Roux emphasised that Van Niekerk had quoted her findings out of context, that syncretism is no problem in an interreligious RE and that students are able to develop their own religiosity as well as to interact with classmates of different religions. And she revealed the desolate character of the former subject Bible Studies in order to show that new ways of RE were and are inevitable. Incidentally, since Cornelia Roux's article, Joey van Niekerk either lost courage or had no further opportunity to publish her views in Die Kerkbode.

At the beginning of the new century Die Kerkbode published articles with two different tendencies. Some of them warned against a neutral $R E^{32}$ or expressed great concern about difficulties regarding religious observances in school. ${ }^{33}$ At the same time differentiation and an opening up became evident. It seems that after meetings of church leaders with President Mbeki and the Minister of Education, Kader Asmal, the tone and content of reports in Die Kerkbode shifted. In the second half of the year 2003 those meetings proved that the government was prepared to listen to the churches and to make some changes to the drafted policy on Religion and Education. In August 2003 Gustav Claassen, the successor of Okkie Raubenheimer and representative of the DRC for RE, expressed satisfaction at the government's greater sensitivity in its policy on RE. ${ }^{34}$ An editorial two weeks later showed the new strategy of the church. Instead of resistance to the government, the preferred response was in support of the government. This is summarised in the last sentence of the

28 See Die Kerkbode, 19.10.2001, article: "Die probleem met "multireligie-onderwys"”.

29 Op. Cit.: "Hoe leer jong kinders om in hulle eie God to glo en om Hom beter te leer ken, lief te kry en te dien as hulle in hulle vormingsjare nie deeglike en suiwer oderrig in hulle eie geloof ontvang nie? Sinkretisme mag dalk die droom en einddoel van die New Agers en die Asmals en die godsdienswetenskaplikes van hierdie wêreld wees, maar dit is beslis nie wat toegewyde en gelowige ouers uit die drie monoteistiese godsdienste vir hulle kinders begeer nie".

30 Op. Cit.

31 Die Kerkbode, 2.11.2001, article: "Religieuse onderrig: die ander kant van die munt".

32 See Die Kerkbode 15.9.2001, "Neutrale 'godsdienste-onderrig"”.

33 See e.g. an article and a comment in the edition of 11.4.2003: "Godsdiens dalk uit skole and Godsdiens op skool bedreig"; in addition to that a cartoon on this question was printed in this Kerkbode-edition; see also the article of 23.5.2003 with the headline "Godsdiensbeleid wek steeds kommer".

34 See Die Kerkbode, 8.8.2003, article: "Godsdiens bly in skole, maar groter duidelikheid kort nog”. 
editorial: Confrontation often is not the best route, rather, (we should choose) continuous pressure, talks and finally persuasion. ${ }^{35}$

Has the DRC now arrived at democracy? It seems so. The moderator of the church, Dr. Coenie Burger, reported in October 2003 in Die Kerkbode that talks with Mbeki and Asmal had helped. One has - as he writes - to pay ongoing attention to this field and there are still one or two things that concern us. ${ }^{36}$ But he felt optimistic after the assurance of the Minister of Education, that his door is open for more talks. ${ }^{37}$

Are all problems solved now? No, there are still alternative opinions expressed in the newspaper of the DRC ${ }^{38}$. Nevertheless, the willingness of the church-leaders to cooperate with the government and to influence church members, has been illustrated; they appear to be more positive about the government's policy in the field of education and not to give complaints only. So the strategy of the DRC has evidently changed. The church leaders noticed that their own interests in the field of RE could be partly accommodated in the new policy-document of the government.

What does this mean for the question of accepting diversity? There is no clear conclusion to be drawn on the basis of official and semi-official statements of the DRC. Perhaps one could say that there is an opening up of possibilities for cooperation with other churches and with the government. What is still lacking, is reference to possible cooperation with other religions in this field, or a concept of an RE that takes the religious diversity in the country into account actively.

If we don't obtain a clear picture on the official and semi-official level, we should direct our attention to another level, to what is happening at grassroots. One sector at grassrootslevel that has a fresh view on what is happening at school, is a community of youngsters, university students. They will, in the near future, be the leaders in the church. Is there any willingness on the side of students to strive for diversity in RE, do they favour a separated confessional RE, or do they opt for public schools without the subject RE?

\section{Students' Perspectives}

What are the opinions of students at the universities of Stellenbosch and Pretoria, who form a small but not unimportant group at grassroots level? In the frame of an empirical investigation on diversity of students we find answers of students with quite different possibilities for a future RE. ${ }^{39}$ Responses were drawn from students who belong to one specific group of the younger generation of South Africans, most of them members of the DRC. Their opinions could be an indicator of the motivations, the aims, the fears and the expectations of this group of young academics, who could, in time, be influential in church and society. Our questions and the answers of students are provisional, opening up the field for more sophisticated research. ${ }^{40}$ We asked them to answer to the following two questions.

35 See article "Godsdiens nié uit skole "verban", 22.8.2003: "Konfrontasie is dikwels nie die beste weg om te volg nie, maar eerder volgehoue druk en gesprek en uiteindelik oorreding".

36 See Die Kerkbode 10.10.2003, article: "Coenie Burger. Moderator skryf: Die Kerk se publieke getuienis". The quoted sentence reads: Daar is egter steeds een of twee dinge wat ons kwel...

37 Op. Cit.: "Dit is bemoedigend dat die minister gesê het sy deur staan oop vir verdere gesprekke".

38 See e.g. the article: "Skole is Christelike onderwys verskuldig aan die wêreld", 14.11.2003 in Die Kerkbode.

39 My data-basis consists of the answers of 1220 students to the following two questions. Thanks to Matthias Gensicke who allowed me to incorporate them in his broader questionnaire (Gensicke, 2003).

40 Such research is needed given the fact that we could include only two questions to the questionnaire of Matthias Gensicke (see footnote 39) and we gather from the answers that the questions are open to possible misunderstandings. 
First: Should there be religious education in public schools? And second: If there should be religious education in public schools, in what form should it be taught? Here are the answers we received:

- Most of the students opt in favour of RE in public schools: $86 \%$ belonging to the DRC, and even $66 \%$ of those who don't belong to a faith community, wrote that RE should be incorporated as a subject in public schools.

- The answers to the second question show that in total about 50\% of the students give high priority to RE where different faith groups are separated; this is especially desired by students with a DRC background (55\%). Concerning the wish to have an integrated $\mathrm{RE}$, it is the other way around. Here the students without church-affiliation preferred joint sessions in RE (24\%), and the DRC-students were more reluctant (12\%). But astonishingly enough, there are still more DRC-students who prefer the possibility of joint sessions to having RE in the form of catechism classes $(8,5 \%)$. Finally, in contrast to the low percentage of DRC-students that expressed preference for catechism classes in school, the number of those with of no church-affiliation who expressed preference for that option, is amazingly high (6\%).

In addition to the two quantitatively structured questions we gave respondents the possibility of free comment on the preferred form of religious education - and many of them made use of it. So we are in the fortunate situation to obtain a much more differentiated picture than would have been possible on a purely quantitative basis, of how the students would like RE to be structured in public schools. Using a qualitative analytic method from the social sciences (Kleining, 1995) I'll try to describe the field of the positions, with special reference to the maximum in the variety of the answers.

The question to the students regarding the form in which RE should be taught in public schools, showed enormous creativity. The students referred mainly to the question whether $\mathrm{RE}$ should be taught to separate religious groups or to learners from various religions in one group. The other two options - catechism classes by church representatives or external teachers - were hardly commented on; the students evidently did not perceive these as being of the same importance as the first two options. In the answers of the students we find rich resources for different arguments in the field of RE. I will present to you the most interesting findings. I concentrate on the students with a DRC-background, but from time to time I also refer to those with other church-affiliations or with none.

\section{What Evidence do we find with Regard to the Preference for Separated RE?}

The students focused on quite different aspects. We find general statements like the following: In my opinion: At all times and for all learners a Christian basis, ${ }^{41}$ as well as

41 (P-329, 1979, 2, DRC, 2, 1: In my opinie: altyd'n Christelike grondslag vir almal, $\mathrm{x}$ ).

Explanation: All quotations in the text are reproduced in the original language, with either the English translation (own translation of the author) in the text and the Afrikaans original in the footnotes or - if there is no Afrikaans translation in the footnotes - they are written in English and directly cited.

The legend for this quote and those following is:

University: $\mathrm{S}=$ Stellenbosch, $\mathrm{P}=$ Pretoria

Year of birth: 19

Gender: Male $=1 ;$ female $=2$

Religious group: $\mathrm{DRC}=$ member of the DRC; other=member of an other church; no church=no churchaffiliation

Decision on should there be RE in public schools (with reference to the first graph): $\mathrm{x}=\mathrm{don}$ 't know, $1=$ against RE in public schools, $2=$ inn favuor of RE in public schools, $\%=$ no answer 
differentiated points of view, like the following: Children should be taught that they should have respect for the faith and world-views of others and that this may differ from their own position. ${ }^{42}$ And there are more interesting explanations. One student insisted that the option for a separated RE should not be regarded as Apartheid, ${ }^{43}$ one other that RE should not be compulsory $^{44}$ and another that it should be structured process-orientated: In Primary school apart, but in Secondary school more independently and together. ${ }^{45}$

Another student spoke out in favour of evangelisation in such a separated RE, but not as obligatory for learners - and religious campaigns should be kept out of school hours. ${ }^{46} \mathrm{We}$ know a little bit more of that student, because she took up the theme of RE a second time, namely in her answer about her feelings on diversity. There she wrote: Diversity is interesting in certain areas and definitely from a democratic perspective it's the right thing to do, but naturally I feel more at home amongst people of the same language and faith, not necessarily the same race group. I know that Christians, true Christians, do not isolate themselves. ${ }^{47}$ What motivation and reasoning lies behind a statement like this? We find an interesting pattern in some answers (also given to the question on diversity), and I quote two of them:

First there is the comment of a DRC-student, that reads: Community: It is mostly connected to income. Education: The measure of diversity may not be enforced at the cost of religion.

Faith: Christian churches should work together more and greater diversity should be encouraged. Language: Language but not the colour of the skin... ${ }^{48}$ And second, there is the comment of a student with no church-affiliation, who spells out more directly what we find typical in many answers: Diversity in the society, in education and language is a good thing. But diversity in religion and sexual orientation is not from god. And if it is not from god then it is from Satan. ${ }^{49}$ And another one without church-affiliation stated: Races should do some things together. Faith issues should not be mixed. Worship in schools should remain as it always was!!! In fact, faith should be intensified, given more support and discussion and be practised more. ${ }^{50}$

In these answers diversity doesn't seem to be a principle that applies either to everything or to nothing. It is evident, that there is a stream of thinking among students that allows for diversity in many different spheres, but not in the sphere of religion and RE. This is interesting and challenging - I come back to this point in my conclusion.

In view of the existence of RE in public schools, we find the most radical alternative in a statement of a student with a charismatic background. She either wants RE in a separated form or, if this were not possible, then not at all in public schools. She writes: If Christianity and Jesus cannot be taught at school, they should rather totally keep it out of

Position with regard to the form of RE (with reference to the second graph): $1=$ separate, $2=$ together, $3=$ catechism class, $4=$ external teachers, $5=$ other, $\%=$ no answer.

42 (P-238, \%, 2, DRC, 1, 1: Om kinders te leer dat hulle respek moet hê vir ander se geloof en oortuigings en dat dit maar kan verskil van hulle eie.2).

43 (S-090, 1981, Male, DRC, 2, 1: Maar moet nie as apartheid gesien word nie,2).

44 (S-785, 1984, Female, DRC, 2, 1: Godsdienstige onderrig moet net nie verplig wees nie, $\mathrm{x}$ ).

45 (S-209, 1982, Male, DRC, 2, 1: As laer skool apart, maar as meer selfstandig - hoër skool-saam, 2).

46 ( P-451, 1984, 2, DRC, 2, 1: Evangelisasie wat nie aan leerders opgedwing word nie, en godsdienstige aksies by die skool buite skoolure, $\mathrm{x})$.

47 (P-451, 1984, f, DRC, 2, 1).

48 (P-074, 1974, m, DRC, 2, 1).

49 (S-092, 1981,m, no church, 2,1).

50 (P-410, 1980, f, no church, 2, 1?). 
school, because six year old children are not strongly rooted in their faith yet and so may be confused. Then it would be better if their parents teach them in their faith. ${ }^{51}$

\section{What about those Students who preferred a Common RE?}

Again I concentrate on the comments of the students of DRC background. Here we don't find as many and explicit comments as with the first choice. Students clarified that RE in such a form should not serve the aim of converting learners to one or the other faith, but rather have the character of a school-subject that incorporates different faiths and is taught by external religious leaders. ${ }^{52}$ Students see the priorities of an integrated RE to be the teaching of common morality and values, and they consider the science of religion as basis for a rational information on different faiths. ${ }^{53}$ Students with no church-affiliation proposed an open minded fair approach ${ }^{54}$ and pleaded that All religions should be studied and comparisons made so that pupils can see for themselves where the truth actually lies in the Christian Bible. ${ }^{55}$ Thus far the opinions on the second item of RE.

The richest source of information on student perceptions lies in the comments of those who deliberately wanted to go for a completely alternative option. Here we find more reasons and a greater variety of differentiation on why students opt for either a separated or an integrated form of RE. I will characterise the general trend and quote some of the statements.

One tendency is to argue against a multi-faith approach to strengthen a Christianorientated or even DRC-orientated RE. Apart from the general advocacy of a DRCorientated RE, ${ }^{56}$ we also find a more general reason given for the necessity of Christian education: Without this foundation the rest of democracy probably will not work. ${ }^{57} \mathrm{We}$ find emotional judgements against a multireligious $\mathrm{RE}$ as well as proposals on how to include other religions in an RE structured and divided by the different confessional and religious backgrounds of the students. For each direction, I give one example. One student wrote: Are you silly? All faiths together? What do you understand by faith? Better no faith in some schools than all of them together... ${ }^{58}$ Another one wrote: Christian Education only ${ }^{59}$ and she explains in a way that we have already noted above: Diversity is acceptable in all

51 (S-723, 1984, Female, Other, 2, 1: As hulle nie net oor Christendom en Jesus kan onderrig nie, moet hulle dit liewers totaal en al los, want ses-jarige kinders is nog nie so sterk in hul geloof gevestig nie en 'n kind kan deurmekaar raak. Laat sy ouers liewers vir hom leer!, 1).

52 (S-464, 1981, Female, DRC, 2, 2. Dit moenie 'n bekeringsklas wees nie, maar 'n onderrigklas, 2); S-582, 1982, Female, DRC, x, 2: Inkorporeer verskillende gelowe,2; P-092, 1976, 1, DRC, 2, 2: Met eksterne religieuse leiers wat dit aanbied. Feitelike basis eerder as evangelisasie. 2).

53 ( P-284, 1974, 2, DRC, 2, 2: Algemene morele waardes wat gesamentlik gesamentlik geleer word; P-341, 1980, 2, DRC, 2, 2: Maar dan moet dit meer iets in die lyn wees van Godsdienswetenskap waar daar op rasionele vlak inligting aan kinders oorgedra word aangaande die gelowe, 2).

54 (S-176, 1982, Male, No church, 2, 2, x).

55 (S-250, 1983, Male, No church, 2, 2, 2).

56 ( S-127, 1981, Male, DRC, 2, 5: NGK georiënteerd wees, \%).

57 (S-167, 1982, Male, DRC, 2, 5: Christelike onderrig - sonder dié fondament sal die res van demokrasie waarskynlik nie werk nie, 2).

58 (S-233, 1983, Male, DRC, x, 5: Is julle laf? Alle gelowe saam? Wat verstaan julle dan onder geloof? Eerder dan geen geloof in enige skool as alle gelowe saam. Die klippe sal die waarheid uitskreeu as die onderwysers dan moet stilbly).

59 (P-439, 1984, 2, DRC, 2, 5: Slegs Christelike onderrig,1). 
aspects of life, but in matters of faith, there is only one way to heaven. ${ }^{60}$ So there is a tendency within those, who did not opt for a separated RE, to go beyond the idea of separating the learners according to their faith - i.e. a separated RE for Christians, Moslems, Hindus etc. but the choice here is to go one step further: To call for a Christian only education - with the implicit but clear wish, that other religions should not be taught at school.

But there is also a second and quite different tendency among the DRC-students. They call for a differentiated approach and an opening up of RE in schools. I restrict myself to three examples. One student calls for change in RE on the basis of history: Apartheid was wrong. Diversity in society is welcome. But also in our education. As long as leaders have the appropriate knowledge and are not simply there because of the colour of their skin, it is fine. Faith [is what counts]. ${ }^{61}$

Another preferred a mixed model by proposing the following: Children should have a general class where they study all faiths, in order to respect the different faiths of each other, but there should be an additional class, where a special study of the special faith of the child takes place. ${ }^{62}$ And one student - with a church-background other than DRC formulated in an amazingly reasonable way: Children should be exposed to other religions so that they can learn to respect other faiths. They should also be allowed to choose what religion they want to follow. Religious leaders like pastors, mullahs, reverends, Buddha priests, etc. should be allowed. Certain important questions should be considered when introducing these religions in schools, like: Are they promoting love among students? Are they lifting moral standards? Are they promoting good deeds?, etc. ${ }^{63}$

A lot of other productive ideas are expressed. They basically differentiate within the abovementioned streams of thinking, so that there is no need to elaborate further.

\section{Conclusion}

I am not going to broadly discuss the different findings of the main part of my paper. My conclusion concentrates on the students' view on RE and the interrelation with the DRC policy in the context of a diverse society. In the end I refer to my findings from a German perspective.

Which conclusions can be drawn from the students' options? In my view three results are worth mentioning:

- The clear answer is that students want RE in public schools.

- There is a broad field of opinions - partly marked by extreme differences - on why and how RE should be structured in schools.

- The state as well as the churches should take into account the abovementioned voices in order to inform themselves on the concrete wishes of those affected by new policies. They need to understand their backgrounds and to thoroughly discuss which demands they are able and willing to meet and which ones not.

60 She gives the quoted answer to the question on her feelings towards diversity in general: (P-439, 1984, $\mathrm{f}$, DRC, 2, 5).

61 Apartheid was verkeerd. Diversiteit in die gemeenskap is welkom. Maar in ons onderwys ook. Solank die mense in die hö̈ poste die mense met die nodige kennis is, en nie agv hulle velkleur nie, is dit fine. Geloof. (S-233, 1983, m, DRC, x, 5).

62 (P-316, 1978, 2, DRC, 2, 5: Kinders moet 'n algemene klas hê waar toeligting oor al die gelowe plaasvind sodat diegene mekaar se verskillende gelowe respekteer, maar oo "n klas addisioneel tot die eerste waar spesifieke toeligting plaasvind in die kind se spesifieke geloof, 2).

63 (P-458, 1977, m, other, 2, 5). 
What does all this mean as resource for structuring RE and for the policy of the DRC? The DRC has to bear in mind that both streams found among the students, present a challenge to them. those who are strictly against any encounter with other religions, correspond to the old thinking in the DRC. Formerly this was linked to power, and in this regard it was effective for the own group. Nowadays such thinking in a pluralistic situation is no longer adequate. The DRC has to learn and to teach its members not to isolate themselves from other religions, but to enhance actively the diversity in the country, and this for four reasons:

First of all, isolation often is closely connected with prejudice and the inappropriate assumption that one is superior to others. We saw this in some students' comments. The DRC has the responsibility to develop and to strengthen a theology that is not based on fear, feelings of superiority and isolation, but one that takes into account that God is not the possession of the church. The best area to start with and to strengthen such developments lies in the arena of public schools.

Secondly, an attitude of superiority and choice for isolation may run the risk of losing an opportunity. If Gordon Mitchell is right - and I suppose he is - that an interreligious RE is the testing-ground for multicultural education and for diversity, then it is highly problematic, not to create space within an RE at school, to open up to, or even to enable experiences in religious diversity. My impression is that the DRC is on its way to accept contemporary forms of RE. But now theologians and church leaders have to pursue this way actively, and convince members to follow them.

Thirdly, there are more than enough students in the DRC who opt for an opening up of RE. The church should not disappoint students who would like an RE at school that combines knowledge of the own and of other students' religion with interactions between students of different cultural and religious backgrounds. For the DRC it could be important to reflect on whether this isn't a field where a shift in theological thinking should have absolute priority for its reputation not only in society but also amongst its church members, especially the youth. Despite some of the comments of students in favour of separation in the religious field I would like to ask: Who will in the long run stick to a church with a theology that is either outdated or consists of a compromise which intends to include everybody at the risk of satisfying nobody?

Fourthly and finally, the possibility mentioned at the beginning of this paper has to be considered, namely that on the one hand accepting diversity in society could accommodate a generally held desire, while on the other hand insistence on one's own cultural and religious identity could meet many personal wishes. Doesn't this comply with the opinion of students quoted above who accept diversity in politics and society, but reject it absolutely for religion and RE? Briefly, the desire to live out religion in a homogeneous religious group has its place predominantly in the parish and the family. RE in school should help students to reflect on their own religious background and it should be made possible for the students to develop and to keep to their convictions. But the boundary at least for RE in schools is drawn at a point where children and students express their own religion in isolation and condemnation of other religions and persons who adhere to other religions.

So personal convictions and societal needs must be balanced in a way that will be mutually enriching without excluding each other. Otherwise religion contributes to intolerance and will be a stumbling block for the acceptance of diversity. In the long run it will only be 
possible to really open up to the diversity in the South African society, if the field of religion is included.

I want to close with a short remark inspired by my German background (Weisse, 1995; 1996 and 2003). In my view politicians are well advised to listen to the opinions of religious representatives - and they do it in a secular state with an amazing openness. Statements like the one cited from the minutes of the synod of the DRC of 2002 contain a substantial resource of wisdom, experience and expectations that cannot be formulated by politicians alone. Religious leaders on the other hand are well advised not to strive for the direct implementation of their own institutional interest alone in the public sphere. They at least have to appreciate the mediation of politicians, state institutions and semi-state institutions like the universities, in order not to limit the perspective of the own institution or of the own faith community. This is necessary in order to avoid paving the way for conflict with other faith groups and at the same time avoid becoming blind to public needs on the level of religious education. So interaction between the different role-players is needed, in order to lay the foundations and to concretely shape an RE that aims to contribute to the development of religious thinking not to the exclusion of others, but in dialogue with the other.

\section{BIBLIOGRAPHY}

Chidester, D 2003. Religion Education in South Africa: Teaching and Learning about Religion, Religions and Religious Diversity. British Journal of Religious Education. 25(4):261-278.

Chidester, D, Mitchell, G, Omar, R \& Phiri, I 1994. Religion in Public Education: Options for a New South Africa. Cape Town: University Press.

Coertzen, P 2002. Freedom of religion and religious education in a pluralistic society. Ned. Geref. Teologiese Tydskrif. 43 (1,2/2002):185-196.

Die Kerkbode, Vol.154 (1994) - Vol.171 (2003).

Greensick, M 2003. Religiosity of students within the DRC. Preliminary empirical findings. Scriptural, International Journal of Bible, Religion and Theology in Southern Africa. 83(2)276-286.

Jackson, R ed. 2003. International Perspectives on Citizenship, Education and Religious Diversity. London and New York: RoutledgeFalmer.

Kleining G 1995. Lehrbuch Entdeckende Sozialforschung. Hamburg: Beltz.

Minutes of the Dutch Reformed Church: Agenda en Handelinge Algemene Sinode 1986, 1990, 1994, 1998, 2002. Published by the DRC, Bloemfontein.

Mitchell, G 1993. Religionsunterricht. Testfall für ein multikulturelles Bildungswesen, Entwicklungspolitische Korrespondenz. 24 (2/93):26-28.

Mitchell, G 2002. Educational Change and Moral Development. Religion and Politics in South Africa. From Apartheid to Democracy, eds. Tayob, A \& Weisse, W Münster/ New York/ München/ Berlin. 111-118.

Mitchell, G and Weisse, W 2001. Internationale Perspektiven religiöser Bildung. Der Bildungsauftrag des Protestantismus, ed. Schweitzer, F. VWGTh, Band 20, Gütersloher Verlagshaus. 295-309.

National Policy on Religion and Education, 2003. National Department of Education. Pretoria: Government Printers. September. 
Roux, C 2000. The Need for the Transformation of Religion in Education: Towards an Understanding of Democratic Values. Democratic Transformation in Education in South Africa, ed. Konrad-Adenauer-Stiftung, Stellenbosch. 109-115.

Swart, FJ 2002. Kerk en Onderwys. 'n Kerkregtelike Studie Van Artikel 67 Van die Kerkorde Van Die Nederduitse Gereformeerde Kerk (1998). Unpublished DTh Thesis, Faculty of Theology, University of Stellenbosch, Stellenbosch.

Weisse, W 1995. Christianity and its Neighbour-Religions: A Question of Tolerance? Impulses for the Education of Religion from the Experience of ecumenical Dialogue Scriptura. International Journal of Bible, Religion and Theology in Southern Africa. 55:263-76.

-- 2003. Difference without discrimination: religious education as a field of learning doe social understanding? International Perspectives on Citizenship, Education and Religious Diversity, ed. Jackson R. London and New York, RoutledgeFalmer. 191-208.

Weisse, W (ed.) 1996. Interreligious and Intercultural Education. Methodologies, Conceptions and Pilot Projects on South Africa, Namibia, Great Britain, the Netherlands, and Germany, Comenius-Institut: Münster. 